\title{
New media for increasing political participation in Indonesia
}

\author{
Uspal Jandevi a,1,*, \\ ${ }^{a}$ Universitas Muhammadiyah Yogyakarta, Jl Ringroad Barat,Yogyakarta, Indonesia \\ 1.uspaljandevi@yahoo.com*; ) \\ * corresponding author
}

ARTICLE INFO

Article history

Received 2019-05-04

Revised 2019-05-04

Accepted 2019-05-28

Keywords

e- Democracy,

Election.

Indonesia,

New Media

\section{ABSTRACT}

This paper aims to corelation among The development of information and communication technology (ICT) encouraging diverse patterns of change including government and public relations in a democracy this research is a library study, a library that contains an in-depth collection of materials for one more subjects. Research libraries usually include primary and secondary sources. In the end we must realize ICT is a tool not a solution for democracy. The main lesson from countries that are able to adopt the principles of e-democracy to improve the quantity and quality of participation of its citizen is a good preparation prior to application in the field.

This is an open access article under the CC-BY-SA license.

\section{Introduction}

25 years ago computer professionals in charge of social responsibility released a timely report as Vive President Al Gore was charting a future internet path. The Group said at the time the internet must promote public and privat interest. This is the blue print for the internet upholds democratic traditions. Facebook users activities in 2007 led to facebook 's democratic decision making. At one point, Facebook agreed that users should vote on changes in corporate policy. But the company changed direction, shut down political groups and blocked the creation of a future user base about Facebook's business practices. Today internet companies are funding academics and NGO against governemnt regulation, further belittling meaningful public discourse [1].

It is not easy to try to assess the status of democracy for today and to understand is democracy is an complex situation and a multidimentional phenomenon, not just importance in election section, civil and political life outside elections must be consistent with our democratic ideals, in particular the characteristics of public discourse exchanges among citizens. Democracy requires a public culture, based on a number of minimum shared values, embodied daily life [2].

Broadcast technology provides a single channel of communication. The public is called the audience. Neither radio nor television is suitable for two-way communication. In terms of culture, the production of radio and television has been linked to the mass consumption process, a process that does not easily meet positive citizenship requirements. Sofa potatoes are rarely a participating citizen. Since the start of the broadcast, however, a group of social commentators have pointed to its potential role in educating the public about democratic citizenship [3]. 
By development of ICT, the one way simple interaction replaced with speed, accuracy and easiness in all matters including state. That requisite responded by internet as one of the most advanced technology from ICT development. The using of internet favoured because interactivity is minimal delay, relatively inexpensive, fast and has a wide range of information. No doubt the economic nature of internet attracted the interest of economic actors for their business; new trends like online shop were spread. In other side, state authorities were convinced with the idea of internet potency that help the democratic process included smoothing participation. The inovation as the effort to improve democracy with the using of electronic service then to be known by term "Edemocracy" [4]. Logically, when the state unable to balance speed of flow of technology, then over time their any offered system will wither and stamped out of date. Againts the flow has a great consequences but followed without any preparation also will not minimize the consequences.

Then it raise a question, how Indonesia should respond addresing democracy phenomenon? Adoption of origin so it will complicate things. Then, how further ICT can contribute to turn on publikkead participation? It is true the easiness interaction between government and public offered by ICT can strengthen the democratic process. What are the crucial matters to be prepared before adopted this idea into policy and other practical activities. This paper attempts to sort out the reaction in response to the prospect of e-democracy for the new life of the Indonesian participation.

\section{Theorical Framework}

\subsection{Democracy, Participation and Internet}

Democracy is an utopian concept, Plato will agreed with the statement [5]. How can be one system able to listen all of citizen voices and involve them in making decision? Overtime, some of the solution echoed related with the participation accomodation, call it the appointment of public representatives in government, the forming of political party in charge of perticular interest, public opinion collected with vote and the last is using of electronic device equipped with the internet as direct channel that connect public and government. Democracy is more understood not as a system centered on the activities of the government, but all efforts to strengthen public participation. Then, whether the option is the use of internet due to the failure of the previous one? In fact it can not be generalized, because each state would face different condition. Although the society who are experiencing the increasing welfare and education tends to demand more political participation and when the demand is not handled correctly then it possible for increasing political participation crisis in the state [6]. ICT with facility offered then considered potentially to fill the void by providing participation opportunities for every people without become public representatives or be the member of political parties, because sometime political parties are not free from bureaucratic gibberish [7].

Indonesia is actually no stranger to the terminology of democracy. The first president of Indonesia, Soekarno even spawned a new concept of democracy which is guided democracy. But the leadership within the old order and the new order, the essence of democracy as a force to favor the people are not strong or intentionally questionable if it will be muted.

Recent post-reform in May 1998 that ouster the new order government, pro-people thinking back carried driven by government policies that have been deemed too repressive coupled with prolonged monetary crisis that makes the most of public have begun speaking openly questioning the existence of government. Public spaces [8] that feel constrained even very limited reap new dilemma about little sense of public participation at that time. Thought participation is one of democracy essence. The whole turmoil is then accumulated and encourages movement that ideally intended to be a change to the country with the protection of democratic values better. Public requires for open access information and government transparancy included the sensitives issues such as election officials and finance [5].

The desire is commonly for public that is being buffeted by modernity. They have willingness to participate in government policies especially related with the welfare of many people lives. If the non-political ways give a greater hope to achieve their goals compared through political channels then the public will tends to invest their time and energy by those non political ways [9].

Do not feel a decade has passed, but the evaluation of democracy assessment is still vague presence. Most believe that Indonesia be progressive but some pessimistic. Mass media is growing and expanding rapidly also has great power that seem also for the formation of public perception 
[10]. But quantity does not mean quality patents, and it is not wise to simply only assess with proliferation of media. In fact, a doubt toward the mass media motive emerge more. One was cause by media ownership in Indonesia is dominated by a handful of party, which in fact besides has economic interest also brought a certain political agenda.

\subsection{Consider Possibility, Reach Opportunities}

Some authors reveal that the mass media does not have any implication on one's political career, but in fact in the various areas of media management and mass public opinion management becomes the defining person's political career. That's why a politician mus more carefully in this internet era[11]. Today is era where privasion is nothing to flourish in countries around the world in the way political and media actors communicate and in individualcountries, interaction will dominate political communication in a similar way.

Political discussion in news programs and other political shows are playing less attention to the non intermediary expression of politician opinions. Mass media and internet coverage presents new challenges for politicians intodeuce they are idea as television journalists focusing on maximizing audience share increasingly shrewdly use dynamic images, dramatic political reporting to maximize the visual and emotional appeal of the show. In turn, political participants are learning to customize their communication efforts in line with the instructions of this new media business. These public figur looking for a way how to provide a variety of questions and image to ensure their playback time and narrow their statements to smaller, more prepared sounds. In their efforts, they are increasingly relying on the guidance of professional strategists and promoters majoring in advertising and public relations [12]. if politics becomes a personal matter then the problems that arise are also personal [13].

The problem is, contemporary media contaminated with economic political interest tends to show the models of propoganda and setting the public perception on a particular event or issues [14]. Concentration of media ownership affects both the individual and community scale. Not only because of the control of the actual frequencies are considered $\mathrm{p}$ ublic domain and limited natural resources (Law 32 of 2002 on Broadcasting) be monopolized but also the media function as provider of diverse ideas, views and information also as the delivery channel public opinion important for democracy was disturbed.

Beside that, culture pluralism supposely manifested into media content also potencial obstructed by homogeneuous setting [15]. The description of this media condition is just a small example of the dynamics of supporting democracy in Indonesia. Intended to see the society participation container has evolved yet again still dim. Become more complex when the recent developments indicate the convergented of mass media with the support of internet [16] then what becomes of the public with the concentration of ownership even in convergent media.

The development of internet network in Indonesia actually already present in the 1990's but not so broad use by general public [17]. Not inconceivable today the internet users in Indonesia has reached 55 million people of estimated 245 million people. More over, the number was 22.4 percent dominate Asia after Japan [18]. If the number is reworded, indeed Indonesia impressed superior so it common when the government saw it as the green light for the democratic practice. But then again, not all of the quantity could be the basic for changing. Moreover with the inequality tendency in Indonesia development, who can guarantee if the internet users is not an individual or a group that focused on several area. Furthermore, if government is too rush implementing e-democracy regardless of the state of field, what can ensure increased community participation even considering not all areas have access to electricity (blank spot) instead of sniffing technology.

Meaning, every changing even need adaptation and preparation. As the development state with wide area distribution, Indonesia need more than raw adoption of developed state policy but also mapping the needs and capabilities per region to support its pre-condition of e-democracy so the effectiveness of e-democracy implementation is capable of running synergistic in national and even international level.

ICT for democracy must be understand not as the solution but a means to achieve the goal. As the means then the useful mean logic not only be seen from the number and scale but if such mean can be effectively and efficiently runs it goals. In addition related with democracy, the focus on the use of technology should not only be emphasized to make things easier and instant. Furthermore is 
must be considered if the using of technology improves the quality of democratic practice and interconnectedness between the government and the governed.

The example, if the reason of government run e-voting (voting used electronic device a kind of computer as opposed to manual system) only that the electoral process be easier then it needs to be studied further since the e-voting will make the voting more credible such guarantee there is no vote inflation. If the resulting effect is the same with the conventional technique, meaning that e-voting have yet to be something urgent to do.

Indonesia government through BPPT (Assestmen and Application of Technology Agency) actually ever held a socialization and e-voting simulation in some areas such as pandeglang, Banda Aceh, Tegal, Gorontalo, and Pasuruan [19]. Jakarta local election in 2012 had also planned to use evoting but not realized. Some of obstacle clearly happening is the difficulties to obtain precise population data despite the making of e-ID card (a sort of citizen identity card (KTP) electronics) has rolled out several month later. In addition, there are no specific regulation that arrange the evoting implementation ranging from the person in charge until the audit method of election result that accountability becomes very vulnerable to questionable.

This paper is not intended to discuss the e-voting but rather identify the ways to channel the public participation through ICTs outside of electoral issues. It is becoming more important because not a lot of mediation can be relied to channel the regular vote. Beside of the mainstream media tend mixed with economic political interest while media and local community also not much of a place in society. In other side, public broadcasting also can not be relied as if life would not hesitate to die because crushed by private business rhetoric. To set the media issue, regulator does not have the power as a significant to face economic power in a handful party or if there are, their activity is not supported with explicit policy that can protect the right of public. The use of ICT in Indonesia is very unfortunate because it seemed more used for issue such as political campaigh online, due to an unwritten culture that attempts to convince the public tends to stop after position available. In fact that should be pursued is the establisment of participatory media for people who want to be involved in the policy process,even especially when one party has been elected as the representative figure in the government.

\section{Method}

Cited by Genevieve [20] Some of the things that the library research researchers have to do are: finding the source needed to be a reference material, this source comes from past researchers and writers. The second is to describe the role of the library material whether the material that was successfully obtained is a primary or secondary reference. A third start to research as needed [21], These three things are very useful in making research libraries [22]. The library is also often the basis of the emergence of field research studies using the questionnaire and so on.

The material that is used as a flat reference is electronic journal [23] And the rest is the data of the working report [24]. Researchers must ensure that the data being referred to always have to be up to date both print data and electronic.

In the United Kingdom there is a lot of research based library research [25], At least there are 2250 researchers who conducted the research of the library there and there are about 300 different sons who are specially provided to facilitate them. Estimated in the future this trend will increase. Based on reports obtained by readers, we are pleased with the findings of the library studies that have been conducted and found the answers they are looking for in various references present from the library [25]. The latest challenge for research activists is how they can develop the teknin in order to facilitate join research with other researchers. And how technology development is able to facilitate the researchers to access the various sources of study that exist around the world [25].

\section{Results and Discussion}

In fact, government portals are meant to open up a lot of space for public participation ended as mere information containers without interactivity between managers (government) and the audience (the public). The online feature that allow direct reciprocity is not managed optimally instead just 
containing content poling or poll that the follow-up result are rarely anounced its usefulness. The event's like treating high technology with traditional methods, a treatment futile.

With this kind of condition: technology infrastructure and system that inadequate, the absence of specific policy that arrange the online participation as well as organizational culture and quality of human resources still need coaching, so it was concluded that Indonesia still have a lot of clean up. E-democracy self have four quadran [26] which can be measured by the government and the public to assess the quality that has been achieved as a source input for further improvement. First, the stage where the government has been able to access information online, but the relationship is still passive and one-way, long stuck in this stage will reduce the posssibility of influencing public policy.

Second quadrant, features such as email and online surveys were introduced to allow the public to 'contact' representatives in the government, the introduction of e-voting in the outlook also included in this stage. While the las quadrant is the highest stage attainable state so far related to the use of ICT for democracy activities which the public is able to influence the government policy by opening up channels for participation such as e-consultation and e-petitions. US already implemented this e-petition method, beside that several European such like Canadian even open information the public policy to international audience. One of the other state that have predicted a succesfull portfolio in adopting the idea of e-democracy to develope portal TOM (meaning "Today I Decide") is initiated by Estonia government. TOM is intended to increase public participation, especially the younger generation to get involved in government policy making. Seem utopian and difficult but proven implemented successful. Why? Data released by the Estonian Government itself that internet usage has reached amount of 45 percent of the population with an estimated 40 percent of the population has had his own computer in each residence [27]. It means, infrastructure technology has meet as the basic consideration of enactment innovation internet usage.

Subsequent study even show that 18 per cent among the users believe that internet can help public to participate in politics. Percentage of those believe can be quite large but reach that number certainly not involve the instant effort and is most likely the government legitimacy by offline in public eye also has strong enough so that when the transformation from offline to online adaptation revolves around the ability of the public to change "channel".

Besides logistic limitation and procedural obstruction, not mean that Indonesia is not able to transform using ICT for increased participation. However, instead of adopting and pursuing the target with a rush policy, prepare condition carefully are more appropriate attitude. Here are somethings to do: Firstly, change the old perspective where the government always react defensive responded public opinion that make public also tends to offensive when related with the government. If the government form is authoritarian, it is only natural to asume flexible in public relation harm ruling authority but by choosing democracy means the position as government elite that come from public and representative should have listened to those that give the power. Listening more often useful compared with spit much word especially to help regulator to identify importance issues for public in order to arrange policy priority.

Second, minimalize the top down policy because the democracy essence it self is listening the people need which mean in every decision making required need mapping and society potential. The government must try, espesiaclly for the public that have high access ability toward technology such as a young age and productive group are not allergic and have interest to participate in political context. Started with giving a prove if public voice listened, that they have competency and especially contribution in government.

The contribution are included in the policy that related with the aegis of the basic necessities of life like food, clothing and shelter, because if the government had considered not transparent and have poor management in that level then there are two possible political implications. First, public will have less willingness to participate in other political matters. Second, public rebelled political system that is assumed as the source of evil. The first position is usually carried out by public in the state with a closed system like in China because the assume any struggles will less helpfull.

Instead the state that implement a more open system where the public used to express need and will have tends to choose second step. Meaning, now if the government is willing to study from the state history it self (see reform 1998), they should understand if their efforts to obscure even 
manipulate public trust will not last longer. Global information distribution will be able to make the public considerate the good and bad the internal condition of Indonesia. The state is also not typical of the country that able have heart to block the exposure of information to tap into aspects of community life, as well as the position of the state is also not as strong as the hegemony of the Chinese government with the 'Great Firewall' of his ruling in limiting government news cons.

Third, build participation channel with the support of ICT accomodated by the goverment or from the public itself. The idea of campaign community should be considered as the concept differently from regular consultation forum. In essence, local communities are educated and introduced to the technology access and also the dynamics of policy-making by parties led by the government but reserved free of government intervention [28]. When they have mastered the technology and can use it to build their own participation channels means that they have reached the stage where people campaigning for himself. Regional autonomy in Indonesia is actually more likely that the concept of community campaign run for mapping and power adaptation of local community more can be seen by the local government with the decentralized power.

Regional autonomy in Indonesia actually more likely that the concept of community campaigns run for mapping and power adaptation needs of local communities could be caught by local governments with decentralized power. Moreover, the locally management relieve the burden on central government and the activity can be monitored well. The central government at least responsible for making cover regulation at national level and submit the regulations details below to local government.

In addition to clarifying the plot of responsibilities with has a guarantee of national legislation, in particular the resources especially the human local resource can be maximally empowered to hand over most of the responsibilities applicable for each region instead of precipitate center people relatively unfamiliar with local situation.

The challenge from this type of channel would come from both sides, the government and public, related with the level of complexity treatment for the incoming opinion. Not all opinion can be implemented by government which would led to public dissapointment. Its adverse affect, the public become cynical and apathetic to participate again in policy issues. But this negative possibility can be minimized by making the poll a priority. It means, set a specific period for input of ideas, grouping issues, numbering priority and disseminating result.

Determination of this period is very important role for the public to know that their claimed aspiration processed by the government. As for when personal aspiration are not included as a policy priority, they still know the reason behind the delay or refusal of their aspiration. By doing so, the confidence to government can be formed and on the other hand such a process would be useful as a form of learning directly to the public in order to reach the essence of deliberative democracy in a state [29].

Anyway community campaign in addition to educate the public know how to participate by electronic as well as make them know step by step to go through before becoming a candidate policy rule, will form a community that is able to be more rational in policy process adressing. The biggest challenge comes from the commitment of both national and local government to separate the interests that tends have agenda setting for their political interest with the public purpose of the program itself.

In contrast, a growing channel from the public level seem more complicated of execution in the field. Not least because the necessary institutions or non-governmental organizations which kind of media is credible and has credibility in public eye. The problems is, it's difficult to find a similar institution especially from media that contaminated by markets and political, unless there is reform of media climate in Indonesia where the public not only valued as objects but as subjects involved. Actually channels coming from grass root can be more ideal than the formation of the government or market based on the assesment of neutrality and detachment from the interest both parties. In essence, this kind of line is made for the public to be able deliver their aspiration without external intervention but has strong enough position to influence the policy.

To enlarge the possible growth of the channel bottom, public should be exposed factual information. The task is really a social responsibility for the media. However, in condition commercializationed media, the government had to intervene to fix the diversion policies to close 
the gap in term of content and ownership. Beside that the government obligated to direct the TIK development in order to bridge the gap between well informed public with poor informed public. Therefore, if public participation only from the rich information it will not affect the quality of democracy.

The fourth step at once of all conclusion is Indonesia should establish the most appropriate concept with itself related the use of ICT adoption. Some things that need to be taken into account is a form of representative institutions (whether the political system is static or dynamic?, whether decentralized or centralized government power? What is the mechanism of public representative?), the role of political party, the mass media position and public attitudes toward technology development [30]. Some of these point have been discussed previously. In addition, if the government plans to start the channel of participation both from above and below through ICT there should be a policy regarding the protection of privacy againts the public so that they can freely express their aspiration.

\section{Conclusion}

E-democracy is not a reality show that must be dressed up to look attractive and dramatic but a real efforts toward the use of ICT that effective and efficient for democratic progress. ICT is a tool not a solution for democracy. The main lesson from countries that are able to adopt the principles of e-democracy to improve the quantity and quality of participation of its citizen is a good preparation prior to application in the field. These preparation include identifying models of government institutions, the role of political parties, the position of the mass media and public attitudes towards the development of technology. Another important point is the continuity and commitment of each element actor in state related with changing perspective in viewing public, decision making also the making of participation channel. Is like the way of luck and pluck Horation Alger, that required tremendous effort sincere and tireless in teaching the rules of the game to get a peaceful prosperity [31].

\section{References}

[1] A. Davis, "Democracy and the Internet," The New York Times, 2018. [Online]. Available: https://www.nytimes.com/2018/10/03/opinion/letters/democracy-internet.html.

[2] Peter Dahlgren, "The Transformation of Democracy," in New Media and Politics, Barrie Axford and Richard Huggins, Ed. California: Sage Publication, 2001, p. 64.

[3] Stephen Coleman, "The Transformation of Citizenship?," in New Media and Politics, Barrie Axford and Richard Huggins, Ed. California: Sage Publication, 2001, p. 109.

[4] Frank Esser and Barbara Pfetsch, Comparing Political Communication: Theories, Cases and Challenge. Cambridge University Press, 2004.

[5] B. Crick, No Title. New York: Oxford University Press, 2002.

[6] M. Amien Rais, Demokrasi dan Proses Politik. Jakarta: LP3ES, 1986.

[7] Syamsuddin Haris, Partai dan Parlemen Lokal Era Transisi Demokrasi di Indonesia. Jakarta: LIPI Press, 2001.

[8] Alan McKee, The Public Sphere: An Introduction. Cambridge University Press, 2004.

[9] Samuel P. Huntington \& Joan Nelson, Partisipasi Politik di Negara Berkembang. Jakarta: PT Rineka Cipta, 1994.

[10] Dennis Mc Quail, “Mass Communication Theory: An Introduction,” London: Sage Publication, 2009, p. 87.

[11] Ken Newton, "The Transformation of Governance?," in New Media and Politics, Barrie Axford and Richard Huggins, Ed. California: Sage Publication, 2001, p. 151.

[12] Sandra Moog and Jeff Sluyter-Beltrao, "The Transformation of Political Communication?," in New Media and Politics, Barrie Axford and Richard Huggins, Ed. California: Sage Publication, 2001, p. 30. 
[13] John Street, "The Transformation of Political Modernity? 210," in New Media and Politics, Barrie Axford and Richard Huggins, Ed. California: Sage Publication, 2001, p. 210.

[14] Edward S. Herman interviewed by Robert W. McChesney, "No Title," in The Political Economy of the Mass Media, 1989.

[15] Gillian Doyle, "Media Ownership," London: Sage Publication, 2001.

[16] Henry Jenkins, "No Title," in The Cultural Logic of Media Convergence: International Journal of Cultural Studies, London: Sage Publication, 2004.

[17] "Bahan Belajar Pengetahuan Populer." [Online]. Available: http://belajar.kemdiknas.go.id/index7.php?display=view\&mod=script\&cmd=Bahan Belajar/Pengetahuan Populer/view\&id=74\&uniq=590. [Accessed: 16-Dec-2018].

[18] "Pengguna Internet di Indonesia Capai 55 Juta Orang." [Online]. Available: http://www.antaranews.com/berita/341397/pengguna-internet-di-indonesia-capai-55-juta-orang. [Accessed: 12-Dec-2018].

[19] "kupas Peluang dan Tantangan Penerapan e-voting di Indonesia BPPT Akan Adakan Dialog Nasional." [Online]. Available: http://www.bppt.go.id/index.php/terkini/58-teknologi-material/1123-kupaspeluang-dan-tantangan-penerapan-e-voting-di-indonesia-bppt-akan-adakan-dialog-nasional. [Accessed: 12-Dec-2018].

[20] Genevieve Hart and Lynn Kleinveldt, "No Title," in The role of an academic library in research: researchers' perspectives at a South African University of Technology, 2011.

[21] A. of S. R. Libraries, "No Title," Association of Southeastern Research Libraries, 2001. [Online]. Available: http://www.aserl.org/statements/competencies/competencies.pdf.

[22] M. Webb, J., Gannon-Leary, P. and Bent, "No Title," in Providing effective library services for research, London: Facet, 2007.

[23] D. . Mgobozi, M.N. and Ocholla, "No Title," . South African J. Libr. Inf. Sci., vol. 2, no. 68, pp. 81-93, 2002.

[24] D. S. Dulle, F W; Lwehabura, M J F; Mulimila, R T. and Mato, "No Title," in Researchers' perspectives on agricultural libraries as information sources in Tanzania, 2001.

[25] A. Brown, S. and Swan, "No Title," in Researchers' use of academic libraries and their services. A report commissioned by the Research Information Network and the Consortium of Research Libraries, London: RIN \& CURL, 2007.

[26] Janet Caldow, "No Title," in E-democracy: putting down global roots. Institute for Electronic Government, 2003, p. 5.

[27] Tex Vertmann, "E- democracy development in Estonia: Case of TOM Portal." [Online]. Available: http://unpan1.un.org/intradoc/images/docgifs/unp_icon_inte_DPADM-UNDESA.gif.

[28] Stephen Coleman and Jay G. Blumer, "No Title," in The Intenet and Democratic Citizenship: Theory, Practice and Policy, Cambridge., 2009.

[29] D. Fadillah, "Pola Komunikasi Internal Brajamusti Menjelang Pilkada Kotamadya Yogyakarta 2017," Informasi, vol. 47, no. 1, 2017.

[30] Kenneth L. Hacker \& Jan van Dijk, "No Title," in Digital Democracy: Issues of Theory and Practice, London: Sage Publication, 2000, p. 66.

[31] James Fallows, Kartu Pos dari Tomorrow Square: Liputan dari China'. Jakarta: PT Elex Media Komputindo, 2009. 